Jurnal Pengabdian Masyarakat Sains Indonesia

\title{
Pelatihan Teknik-Teknik Analisis Instrumen Penilaian Ranah SMPN 21 Mataram
}

\author{
Nur Lestari $^{1 *}$, Gito Hadiprayitno ${ }^{1}$, Muhlis ${ }^{1}$, M. Yamin ${ }^{1}$, M. Liwa Ilhamdi ${ }^{1}$ \\ ${ }^{1}$ Program Studi Pendidikan Biologi, FKIP Universitas Mataram, Mataram, Indonesia
}

DOI: https://doi.org/10.29303/jpmsi.v2i1.8

Citation: Lestari, N., Hadiprayitno, G., Muhlis., Yamin, M., Ilhamdi, M. L. 2020. Pelatihan Teknik-Teknik Analisis Instrumen Penilaian Ranah SMPN 21 Mataram. Jurnal Pengabdian Masyarakat Sains Indonesia (JPMSI). 2(1): 36-39.

\begin{abstract}
Article history
Received: November $10^{\text {th }} 2019$

Revised: December $13^{\text {th }} 2019$

Accepted: December $31^{\text {th }} 2019$

*Corresponding Author: Nur

Lestari, FKIP Universitas

Mataram, Mataram, Indonesia;

Email:

nurnyunglestari@gmai.com
\end{abstract}

\begin{abstract}
Abstrak:Berdasarkan UU Guru dan Dosen Tahun 2005 dinyatakan bahwa salah satu tanggung jawab guru secara profesional dalam kegiatan pembelajaran ialah merancang perangkat pembelajaran. Perangkat pembelajaran yang dimaksud terdiri dari rencana pelaksanaan pembelajaran (RPP), pengembangan media, LKPD, bahan ajar dan instrument penilaian pembelajaran. Namun demikian integritas kesesuaian antara perangkat pembelajaran dan ketercapaian tujuan pembelajaran akan terlihat pada pelaksanaan assessment autentiknya. Ditemukan bahwa guru-guru SMPN di Kota Mataram hanya memilki arsip soal yang tidak dilakukan analisis kualitas. Padahal analisis kualitas butir soal merupakan hal penting yang harus dilakukan oleh guru dalam mengarsipkan soal-soal tes menjadi bank soal. Oleh karena itu perlu dilakukan pelatihan tentang teknik-teknik analisis butir soal menggunakan software bebasis komputer, ynag bertujuan untuk (1) melatih guru-guru di SMPN 21 Mataram untuk membuat soal objektif dan subjektif yang sesuai dengan kaidah-kaidah pembuatan soal yang valid dan reliabel, (2) melatih guru-guru yang ada di SMPN 21 Mataram untuk melakukan analisis butir soal dengan menggunakan software komputer, dan (3) melakukan kegiatan pendampingan pada guru-guru yang ada di SMPN 21 Mataram untuk melakukan analisis butir soal pada alat evaluasi yang digunakan di sekolah. Pelaksanaan kegiatan pengabdian ini berjalan dengan lancar ditandai dengan adanya respon positif dari peserta pengabdian yaitu guru-guru SMPN 21 Mataram. Tim pengabdian menguraikan banyak hal mengenai kajian teori teknik-teknik analisis soal objektif dan subjektif kemudian guru mencoba melakukan analisis butir soal menggunakan software komputer bersama-sama. Program pengabdian ini dapat ditindaklanjuti dengan kegiatan penyusunan soal sesuai topic per mata pelajaran dan berdasarkan taksonomi pendidikan sehingga bemanfaat bagi guru yang akan menganalisis mutu instrument soal.
\end{abstract}

Kata kunci:analisis instrumen, penilaian, ranah kognitif, SMP 21 Mataram

\section{Pendahuluan}

Berdasarkan UU Guru dan Dosen Tahun 2005 dinyatakan bahwa salah satu tanggung jawab guru secara profesional dalam kegiatan pembelajaran ialah merancang perangkat pembelajaran. Perangkat pembelajaran yang dimaksud terdiri dari rencana pelaksanaan pembelajaran (RPP), pengembangan media, LKPD, bahan ajar dan instrument penilaian pembelajaran.Namun demikian integritas kesesuaian antara perangkat pembelajaran dan ketercapaian tujuan pembelajaran akan terlihat pada pelaksanaan assessment autentiknya (Fox et al., 2017).Mengacu pada hasil penelitian yang dilakukan oleh Lestari et al, (2018) ditemukan bahwa guru-guru SMPN di Kota Mataram hanya memilki arsip soal yang tidak dilakukan analisis kualitas.Padahal analisis kualitas butir soal merupakan hal penting yang harus dilakukan oleh guru dalam mengarsipkan soal-soal tes menjadi bank soal (Sudjana, 2010).

Syarat utama dalam membuat bank soal, salah satu di antaranya ialah melakukan analisis kualitas butir soal. Baik soal-soal yang mencakup ranah kognitif, psikomotorik, maupunranah afektif 
(Taufiq, 2015). Tahapan yang dilakukan dalam menganalisis butir soaldi antaranyaialah menentukan validitas, reliabilitas, tingkat kesukaran dan tingkat daya beda serta kualitas pengecoh pada soal objektif (Septiana, 2016). Pada umumnya, analisis butir soal oleh guru selama ini dilakukan secara manual menggunakan alat bantu kalkulator. Padahal dalam era digital saat ini,telah tersedia software berbasis komputer yang digunakan untuk menganalisis butir soal.Beberapa software yang dapat digunakan di antaranya ialah Anates, AnBuso, dan SPSS(Lestari, 2015).

Hasil observasi pada guru-guru di SMPN 21 Mataram menunjukkan bahwabelum ada guru yang menggunakan software berbasis komputer tersebut dalam melakukan analisis butir soal. Oleh karena itu, soal-soal yang dibuat oleh guru-guru di SMPN 21 Mataram jarang sekali dilakukan analisis kualitas butir soal. Hal ini berdampak pada kualitas bank soal yang dibuat oleh guru-guru di SMPN 21 Mataram memiliki kualitas yang rendah. Oleh karena perlu dilakukan pelatihan tentang teknikteknik analisis butir soal menggunakan software bebasis komputer, ynag bertujuan untuk (1) melatih guur-guru di SMPN 21 Mataram untuk membuat soal objektif dan subjektif yang sesuai dengan kaidah-kaidah pembuatan soal yang valid dan reliabel, (2) melatih guru-guru yang ada di SMPN 21 Mataram untuk melakukan analisis butir soal dengan menggunakan software komputer, dan (3) melakukan kegiatan pendampingan pada guru-guru yang ada di SMPN 21 Mataram untuk melakukan analisis butir soal pada alat evaluasi yang digunakan di sekolah.

\section{Metode}

Metode Pelaksanaan yang diterapkan pada kegiatan pengabdian ini berupa pelatihan yang ditekankan dalam bentuk praktek langsung dan pembimbingan yang sifatnya mentoring.Pertama diberikan pemahaman tentang teknik-teknik analisis soal objektif dan subjektif.Aplikasinya pada pembelajaran dan manfaatnya yang diperoleh guru-guru, setelah itu melakukan praktek langsung implementasi dan tindak lanjut.Kemudian kembali ke sekolah untuk meninjau kembali hasil latihan yang telah disusun bersama teman sejawat sesuai kelompok bidang studi dan diberikan penjelasan meluruskan atau meriviu hasil latihan.

Adapun langkah-langkah kegiatan pelatihan yang akan dilakukan dapat diliat pada gambar 1 . pada tahap persiapan dilakukan analisis kebutuhan penyusunan materi pelatihan koordinasi dengan pihak sekolah serta penyusunan jadwa pelaksanaan kegiatan. Tahap pelaksanaan akan diberikan informasi tentang kajian teoritis teknik-teknik analisis soal objektif dan subjektif. Tahap pembimbingan dan monitoring akan dilakukan analisis butir soal objektif dan subjektif yang dibuat oleh guru menggunakan software berbasis komputer. Tahap evaluasi dan pelaporan akan dilakukan analisis untuk mengetahui ketercapaian dari tujuan kegiatan pelatihan.

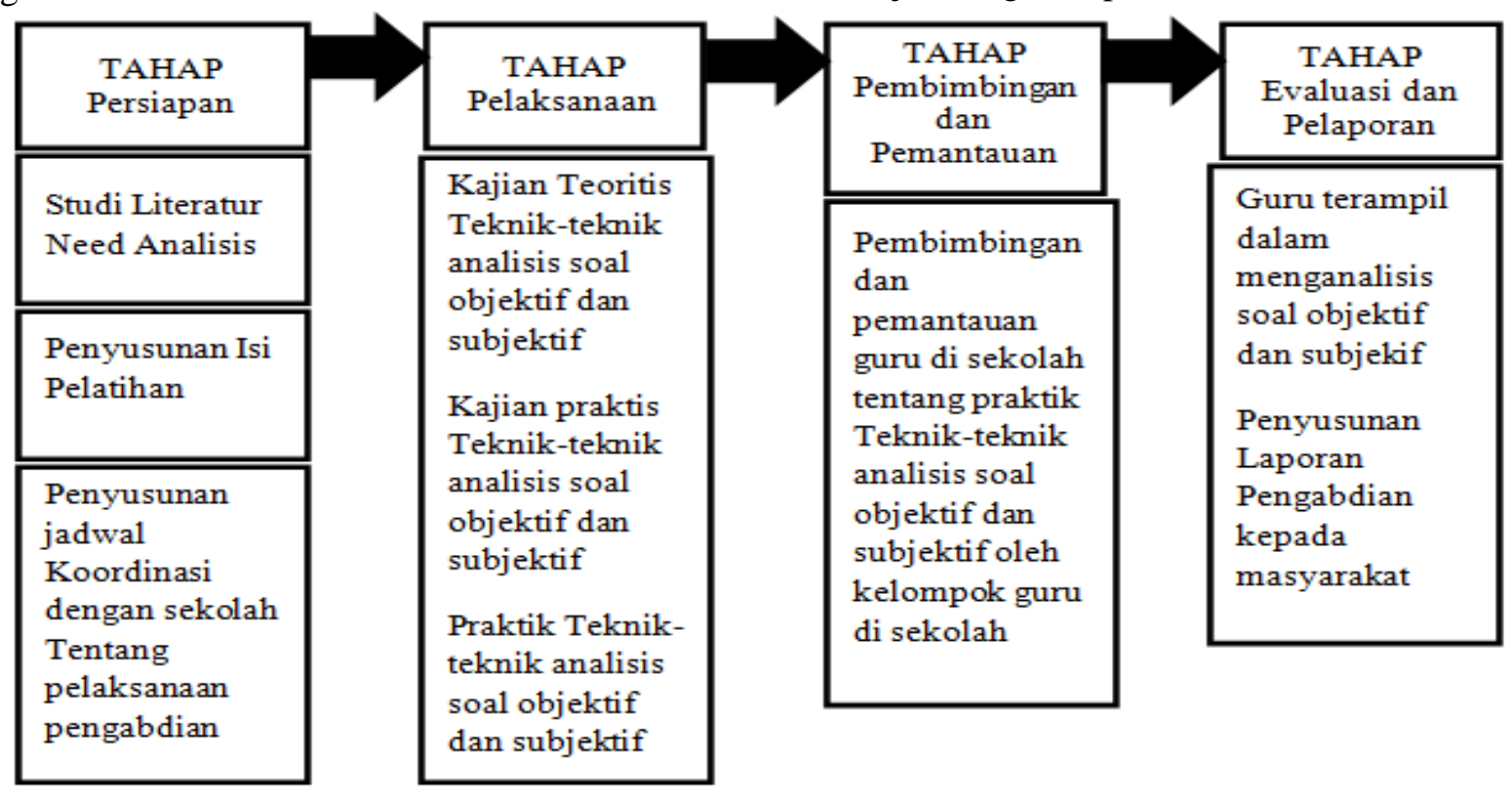

Gambar 1 Tahapan Pelaksanaan Kegiatan 


\section{Hasil dan Pembahasan}

Kami tim pengabdian mengadakan observasi dan pendekatan ke SMPN 21 Mataram yang diterima langsung oleh wakil kepala Sekolah bagian kurikulum dan kami tim mengadakan kesepakatan memberikan pelatihan langsung kepada salah satu guru sebagaiSebelum kegiatan pengabdian masyarakat ini dilaksanakan, belum ada guru yang menggunakan software berbasis komputer tersebut dalam melakukan analisis butir soal. analisis butir soal oleh guru selama ini dilakukan secara manual menggunakan alat bantu kalkulator. Padahal dalam era digital saat ini,telah tersedia software berbasis komputer yang digunakan untuk menganalisis butir soal. Hal ini berdampak pada kualitas bank soal yang dibuat oleh guru-guru di SMPN 21 Mataram memiliki kualitas yang rendah. Jika soal yang dibuat memiliki kualitas yang rendah, maka akan berdampak pada tingkat kompetensi siswa yang rendah pula.

Pada awalnya tim pengabdian mengenalkan aplikasi SPSS pada gurukarena guru belum familiar dengan aplikasi tersebut, sehingga banyak kebingungan. Tim pengabdian mulai mengenalkan dari menu-menu yang ada pada aplikasi SPSS sebelum masuk kedalam contoh cara perhitungan analisis butir soal. Setelah guru memahami fungsi dari masing-masing setiap menu, tim pengabdian mulai memberikan contoh untuk analisis butir soal dari tingkat yang sederhana ke yang lebih rumit.

Selama kegiatan pengabdian berlangsung, guru terlibat secara antusias saat kegiatan yang ditandai adanya komunikasi yang 2 arah.Pendampingan diawali dengan pemberian informasi mengenai kajian teoritis teknik-teknik analisis soal objektif dan subjektif.Teknik-teknik soal obyektif secara manual yang memenuhi syaratsyarat instrument. Soal-soal yang mencakup validitas, reliabilitas, tingkat kesukaran dan tingkat beda soal dan melanjutkan latihan menggunakan kalkulator, excel, SPSS yang dilanjutkan dengan penerapan/ aplikasi menggunakan program Anates dan AnBuso (penyampaian secara rinci dapat dilihat pada lampiran). Guru menyimak informasi yang diberikan dan sesekali menimpali dengan pertanyaan. Selanjutnya pada tahap pembimbingan dan monitoring, dilakukan analisis butir soal objektif dan subjektif yang dibuat oleh guru menggunakan software berbasis computer.Banyak guru yang bertanya karena masih mengalami kesulitan menggunakan software SPSS. Semua pertanyaan dan tanggapan dari guru diberikan respon dan feedback dari tim dosen pendampingan. Setelah semua kegiatan pelatiahan dan pendampingan selesai dilakukanlah evaluasi.

Faktor pendorong kegiatan pengabdian ini adalah antusiasme guru untuk mempelajari analisis butir soal yang baik dan tepat sehingga dapat menghasilkan kualitas butir soal valid dan mendapatkan kumpulan soal yang baik dan terukur. Faktor Penghambatnya adalah belum familiarnya aplikasi SPSS untuk sebagian guru, sehingga mengharuskan satu pendamping untuk satu guru, oleh karena itu tim pendampingan dibantu oleh beberapa mahasiswa.

\section{Kesimpulan}

Pelaksanaan kegiatan pengabdian ini berjalan dengan lancar ditandai dengan adanya respon positif dari peserta pengabdian yaitu guruguru SMPN 21 Mataram.Tim pengabdian menguraikan banyak hal mengenai kajian teori teknik-teknik analisis soal objektif dan subjektif kemudian guru mencoba melakukan analisis butir soal menggunakan software komputer bersamasama.

\section{Saran}

Program pengabdian ini dapat ditindaklanjuti dengan kegiatan penyusunan soal sesuai topik per mata pelajaran dan berdasarkan taksonomi pendidikan sehingga bemanfaat bagi guru yang akan menganalisis mutu instrument soal.

\section{Ucapan Terima Kasih}

Tim Pengabdian pada Masyarakat mengucapkan terimaksih kepada pihak Universitas Mataram yang telah memberikan kesempatan dan mendanai kegiatan pengabdian ini melalui dana DIPA BLU Universitas Mataram Tahun Anggaran 2019.

\section{Daftar Pustaka}

Fox, J., Freeman, S., Hughes, N., and Murphy, V. (2017). Keeping It Real; A Review of the Benefits, Challenges and Steps 
Lestari et al, Jurnal Pengabdian Masyarakat Sains Indonesia 2020, 2 (1):36-39 DOI : https://doi.org/10.29303/ipmsi.v2i1.8

Towards Implementing Authentic Assessment. Journal of Teaching and Learning in Higher Education 9(3): 2801-2813.

Kementerian Pendidikan dan Kebudayaan Direktorat Jenderal Pendidikan Dasar dan Menengah Direktorat Pembinaan Sekolah Menengah Pertama.2016. Panduan Penilaian oleh Pendidik dan Sarana Pendidikan untuk Sekolah Menengah Pertama.Jakarta : Kementrian Pendidikan dan Kebudayaan Direktorat Jenderal Pendidikan Dasar dan Menengah Direktorat Pembinaan Sekolah Menengah Pertama.

Lestari, N., \& Hadiprayitno, G. (2015). Buku Ajar Evaluasi Pembelejaran Biologi. Gunugsari: Arga PujiPress.

Lestari N., Merta, I.W., \&Kusmiyati.(2015). Jurnal Penelitian Pendidikan IPA Profil Asessmen Autentik pada GuruGuru di SMP Negeri seKota Mataram. (JPPIPA@unram.ac.id, website :http://jppipa.unram.ac.id/index.php/jp pipa/index

Mendikbud.(2016). Permendikbud No. 59 Tahun 2014 tentang Kurikulum 2013 Sekolah Menengah Atas/Madrasah Aliyah.Jakarta : Kemendikbud.

Mendikbud.(2016). Permendikbud No. 21 Tahun 2016 tentang Standar Isi Pendidikan Dasar dan Menengah. Jakarta : Kemendikbud.

Pusat Penilaian Pendidikan Balitbang Kemendikbud. (2017). Panduan Penulisan Soal 2017 SMP/MTs. Jakarta : Pusat Penilaian Pendidikan Balitbang Kemendikbud.

Septiana, N. (2016). Analisis Butir Soal Ulangan Akhir Semester (UAS) Biologi Tahun Pelajaran 2015/2016 Kelas X dan XI pada MAN Sampit. EduSains 4(2): 115-121.

Sudjana, N. (2010). Penilaian Hasil dan Proses Blajar dan Mengajar. Bandung: Remaja Rosdakarya.
e-ISSN : $2715-2537$ p-ISSN : 2715-2545

Taufiq, A.U. (2015). Pengembangan Tes Kognitif Berbasis Revisi Taksonomi Bloom pada Materi Sistem Reproduksi untuk Siswa SMA.Jurnal Biotek 3(2): 1-17. 